\title{
Kinerja Pegawai Dengan Faktor Pengaruh Motivasi Kerja Pada Pegawai Dinas Pengelolaan Sumber Daya Air Provinsi Lampung
}

\author{
Hesti Widi Astuti ${ }^{1 *}$, Iwan Zulfikar ${ }^{1}$, Winarto Hadi Saputra ${ }^{1}$ \\ ${ }^{1}$ Universitas Sang Bumi Ruwa Jurai \\ *Correspondence: hesti172112@gmail.com
}

\begin{abstract}
Abstrak.
Tujuan penelitian ini untuk mengetahui Kinerja Pegawai dipengaruhi Motivasi Kerja pada Dinas Pengelolaan Sumber Daya Air Provinsi Lampung. Teknik pengumpulan data menggunakan observasi, wawancara, dan kuesioner. Populasi dalam penelitian ini adalah seluruh pegawai Dinas Pengelolaan Sumber Daya Air Provinsi Lampung berjumlah 195 pegawai, dalam Teknik pengambilan sampel yang dipakai adalah random sampling sehingga didapat sebanyak 30 pegawai sebagai responden. Alat analisis dalam penelitian ini adalah Uji regresi linier sederhana menggunakan uji-t dengan bantuan program SPSS versi 21. Hasil penelitian ini didapat nilai Sig. dibawah 5\% atau Alpha $<0,00$ maka dapat disimpulkan bahwa bahwa terdapat pengaruh positif dan signifikan Motivasi (X) terhadap Kinerja Pegawai (Y).
\end{abstract}

Kata kunci: Aparatur Sipil Negara, Dinas Pengelolaan Sumber Daya Air, Kinerja Pegawai, Motivasi Kerja.

\begin{abstract}
.
The purpose of this study was to determine the performance of employees who are influenced by work motivation at the Water Resources Management Office of Lampung Province. Data collection techniques using observation, interviews, and questionnaires. The population in this study were all employees of the Lampung Province Water Resources Management Service, totaling 195 employees, the sampling technique used was random sampling so that as many as 30 employees were obtained as respondents. The analytical tool in this study is a simple linear regression test using a t-test with the help of the SPSS version 21 program. The results of this study obtained the value of Sig. below 5\% or Alpha $<0.00$, it can be concluded that there is a positive and significant influence between motivation $(X)$ on employee performance $(Y)$.
\end{abstract}

Keywords: State Civil Apparatus, Department of Water Resources Management, Employee Performance, Work Motivation.

\section{PENDAHULUAN}

Pegawai atau karyawan sebagai individu merupakan bagian terpenting dalam mencapai tujuan perusahaan (Wahyuningsih et al., 2019). Pegawai memiliki peranan besar sebagai aset perusahaan (Hakim, 2020), memaksimalkan peran dan fungsinya (Syarif \& Faurin, 2020), juga produktivitas maupun efektivitas organisasi (Ufaira \& Hendrian, 2019). Seluruh sumber daya yang ada dalam perusahaan harus dapat dimanfaatkan sebaik mungkin, termasuk sumber daya manusia sebagai faktor utamanya (Astuti \& Tantowi, 2017).

Kinerja Pegawai Aparatur Sipil Negara

(ASN) sering mendapat sorotan dari berbagai kalangan (Fathurrochman, 2017), image yang tercipta dari PNS terlanjur buruk (Amirullah, 2019; Rozi, 2019), seperti kurang produktif, menghamburkan uang negara, rendahnya etos kerja, sering tidak masuk kerja tanpa alasan yang jelas, tidak sungguh-sungguh mematuhi peraturan jam kerja dan sebagainya.

Tingkat kinerja pegawai masih dibilang rendah (Rozi, 2019) karena kebanyakan dari mereka hanya datang, mengisi absen, 
ngobrol, lalu pulang tanpa memberikan jasa mereka dalam pekerjaan yang dapat mewujudkan tujuan bersama suatu organisasi pemerintah (Sulaeman, 2019). Hal ini akan berakibat tidak baik bagi organisasi, sehingga beberapa pekerjaan tidak diselesaikan tepat waktu (Arifuddin \& Napirah, 2015). Bagaimanapun majunya teknologi saat ini, faktor manusia tetap memegang peranan penting bagi keberhasilan suatu organisasi (Ramadhan \& Astuti, 2017).

Pemerintahan yang baik akan selalu mengembangkan dan menerapkan prinsipprinsip profesionalitas, akuntabilitas, transparansi, pelayanan prima, demokrasi, efesiensi, efektifitas, supremasi hukum, dan dapat diterima oleh seluruh masyarakat (Netha \& Tunti, 2021). Oleh sebab itu untuk menjamin penyelenggaraan tugas pemerintahan dan pembangunan secara berdayaguna dan berhasil guna, diperlukan peningkatan kinerja pegawai dengan beberapa cara misalnya melalui pendidikan, pelatihan, pemberian kompensasi yang layak, menciptakan lingkungan kerja yang kondusif dan pemberian motivasi (Sutarmiyati \& Astuti, 2019).

Kinerja merupakan hasil yang terukur dicapai oleh individu atau organisasi dalam pelaksanaan tugas pokok dan fungsinya (MS et al., 2018). Penilaian kinerja merupakan kegiatan wajib bagi setiap organisasi (Widhiyaningrat \& Idayati, 2015) karena untuk untuk menilai keberhasilan suatu perusahaan (Astawa et al., 2020) dan memastikan bahwa tim atau personel dalam suatu organisasi melakukan tugas dengan baik dalam mengimplementasikan strategi (Herawati et al., 2018) Untuk organisasi pelayanan publik, informasi mengenai organisasi lainnya tentu sangat berguna untuk sebab dapat digunakan untuk menilai seberapa jauh pelayanan yang diberikan oleh organisasi memenuhi harapan dan memuaskan pengguna jasa (Srianti et al., 2020). Dengan melakukan penilaian terhadap kinerja, maka upaya untuk memperbaiki kinerja bisa dilakukan secara lebih terarah dan sistematis (Kurniaty, 2021; Tinompo et al., 2016).

Kinerja pegawai negeri dalam penerapan hasilnya adalah Abdi Negara yang memberikan pelayanan kepada masyarakat memberikan pelayanan sesuai Tupoksinya masing-masing (Triyanto, 2017). Terlaksanakanya Suatu layanan prima jika pelayananan tersebut dapat memuaskan penggunanya apabila Dilakukan pengukuran mengenai profil pegawai yang mencerminkan sikap senang, mengerti kebutuhan pengguna, ikhlas serta tulus melayani pengguna layanan (Dapahari, 2019). Pelayanan kepada masyarakat dapat dilakukan dengan berhadapan langsung yakni dimana masyarakat datang langsung ke Lembaga pemerintah untuk mengadukan, menginspirasikan dan atau lainnya semisal kebutuhannya yang memang harus dilakukan pada Lembaga pemerintah. Selain itu ada juga pelayanan kepada masyarakat dimana masyarakat langsung merasakan manfaat dari peran kelembagaan pemerintah tersebut.

Pegawai Dinas Pengelolaan Sumber Daya Air Provinsi Lampung yang merupakan bagian dari Kementerian PUPR dimana segala pertanggung jawabannya akan menjadi laporan kepada Kementerian PUPR dan dalam pelaksanaannya di daerah adalah melakukan kerja sebagai dasar membantu kepala wilayah (Gubernur), maka motivasi kerja menjadi harapan dan arahan dari setiap PNS Dinas Pengelolaan Sumber Daya Air Provinsi Lampung.

Keberhasilan instansi dalam mencapai tujuan tersebut cerminan dari pegawai negeri (Aparatur Sipil Negara) sebagai aparatur pemerintah dan sebagai abdi masyarakat. Mereka juga dituntut untuk selalu bekerja dengan semangat yang tinggi sehingga dalam memberikan pelayanan kepada masyarakat tidak terkesan lamban, malas dan ogah-ogahan. Semangat kerja 
bagi pegawai negeri diperlukan untuk meningkatkan pelayanan kepada masyarakat. Mereka memberikan hasil kerja berdasarkan syarat-syarat pekerjaan yang ada di dalam setiap Kantor/Dinas tempatnya bekerja.

Upaya untuk memotivasi kinerja PNS perlu disusun pola karir dan pengembangan karir yang memungkinkan potensi PNS dikembangkan secara optimal (Puspitapuri, 2017). Hal ini dilakukan dalam rangka misi organisasi pemerintah yang akhirnya pencapaian tujuan nasional dapat dilaksanakan secara lebih efektif. Motivasi tersebut merupakan kekuatan penting yang harus ada dalam diri pegawai dalam menghadapi situasi kerja yang menggerakkan dirinya secara terarah untuk mencapai tujuan kerjanya dalam rangka pencapaian tujuan organisasi (Jufrizen, 2017).

Berdasarkan survey pendahuluan yang dilakukan, diperoleh keterangan bahwa kinerja pegawai di Dinas Pengelolaan Sumber Daya Air Provinsi Lampung tergolong masih belum maksimal. Seharusnya pegawai yang berkualitas adalah pegawai yang kinerjanya dapat memenuhi target atau sasaran yang ditetapkan (Heryani et al., 2021), memiliki kecakapan untuk menguasai setiap pekerjaan sesuai dengan profesi (Buulolo et al., 2021), serta mampu memelihara dan meningkatkan kecakapan dan kemampuannya secara teratur dan pasti (Nursin, 2018).

Kinerja pegawai di Dinas Pengelolaan Sumber Daya Air Provinsi Lampung masih harus dilakukan perbaikan pada umpan balik yang kurang direspon oleh pegawai, seperti masih adanya yang tidak datang tepat waktu sesuai jadwal yang ditetapkan yaitu jam 07.30 sampai jam 16.00 meskipun sudah ada himbauan dari pimpinan, walaupun datang tepat waktu atau lebih cepat tetapi mereka tidak langsung melakukan aktivitas kerja kebanyakan pegawai sibuk dengan urusan pribadi mereka.

Selain itu juga masih ada pegawai yang selama waktu satu tahun selalu ada saja yang tidak masuk kerja walaupun ada bukti dengan beberapa keterangan dari dokter bahkan ada saja dari beberapa pegawai apabila menjalankan tugas luar sangat sering melebihi waktu yang diberikan sesuai SPT (Surat Perintah Tugas). Untuk melihat tingkat kehadiran pegawai pada Dinas Pengelolaan Sumber Daya Air Provinsi Lampung dapat dilihat pada table berikut :

Dari data yang didapat lalu dianalisis menggunakan uji-t sehingga mendapatkan hasil sebagai berikut.

Tabel 1. Jumlah Pegawai dan Tingkat Kehadiran Pegawai Dinas Pengelolaan Sumber Daya Air Provinsi Lampung tahun 2020

\begin{tabular}{|c|c|c|c|}
\hline No & $\begin{array}{l}\text { Bidang/ } \\
\text { Seksi }\end{array}$ & $\begin{array}{l}\text { Jumlah } \\
\text { Pegawai }\end{array}$ & $\begin{array}{l}\text { Akumulasi Absensi } \\
\text { (Hari) }\end{array}$ \\
\hline 1 & $\begin{array}{l}\text { Seksi Pembangunan dan Rehabilitasi Jaringan Irigasi dan } \\
\text { Rawa }\end{array}$ & 45 & 540 \\
\hline 2 & $\begin{array}{l}\text { Seksi Pembangunan dan Rehabilitasi Infrastruktur Sungai, } \\
\text { Danau dan Pantai; }\end{array}$ & 58 & 696 \\
\hline \multirow[t]{2}{*}{3} & $\begin{array}{l}\text { Seksi Pembangunan dan Rehabilitasi Infrastruktur Waduk, } \\
\text { Bendung dan Bangunan Air Lainnya }\end{array}$ & 92 & 1.124 \\
\hline & Jumlah & 195 & 2.360 \\
\hline
\end{tabular}

Berdasarkan keterangan mengenai kehadiran dari jumlah 195 orang pegawai Dinas Pengelolaan Sumber Daya Air Provinsi Lampung, dapat disimpulkan bahwa dalam 1 hari kerja, terdapat sekurangnya 6 pegawai yang tidak hadir di kantor. tingkat kehadiran pegawai seperti pada table di atas tentu saja berpengaruh dengan hasil pekerjaan sebagai bentuk kinerja. 
Dari hasil observasi juga didapat bahwa masih ada pegawai pada Dinas Pengelolaan Sumber Daya Air Provinsi Lampung yang kurang memahami tingkat pencapaian pelaksanaan suatu kegiatan/program/kebijaksanaan dalam mewujudkan sasaran, tujuan, misi dan visi organisasi yang tertuang dalam perumusan skema starategi (strategi planning) suatu organisasi (Orocomna et al., 2018).

Penelitian terdahulu sudah banyak dilakukan, antara lain penelitian oleh Kristianti, dkk (2021) mengenai pengaruh motivasi dan disiplin kerja terhadap kinerja pegawai pada Dinas Pariwisata Purwakarta. Hasil penelitian tersebut menjabarkan bahwa motivasi berpengaruh signifikan terhadap kinerja pegawai sebesar $42,4 \%$ (Kristianti et al., 2021). Penelitian oleh Alhusaini, dkk (2020) mengenai Pengaruh Motivasi Kerja Dan Disiplin Kerja Terhadap Kinerja Guru Di SMA Negeri OKU. Hasil penelitian menjabarkan bahwa ada pengaruh yang signifikan motivasi kerja terhadap kinerja guru (Alhusaini et al., 2020). Dan penelitian oleh Nurhasanah, dkk (2021) mengenai Pengaruh Disiplin Dan Motivasi Kerja Terhadap Kinerja Pegawai Pada Kantor UPT Pengelolaan Irigasi Bah Bolon Dinas Sumber Daya Air Cipta Karya Dan Tata Ruang Provinsi Sumatera Utara didapat hasil bahwa variabel motivasi kerja dapat dikatakan baik dari sasaran kinerja pegawai maupun perilaku kerja .

Dari uraian dan penelitian terdahulu, penelitian ini bertujuan untuk mengetahui Kinerja Pegawai dipengaruhi Motivasi Kerja pada Dinas Pengelolaan Sumber Daya Air Provinsi Lampung.

\section{METODE PENELITIAN}

Penelitian ini dilaksanakan kepada pegawai Pegawai Dinas Pengelolaan Sumber Daya Air Provinsi Lampung. Teknik pengumpulan data dengan observasi, wawancara dan kuesioner. Populasi dalam penelitian ini adalah pegawai Dinas Pengelolaan Sumber Daya Air Provinsi Lampung berjumlah 195 pegawai. Pengambilan sampel semnggunakan Teknik Random Sampling sehingga didapat 30 pegawai sebagai responden. Analisis kuantitatif dengan metode statistik yang digunakan adalah analisis regresi linear sederhana. Metode analisis regresi linear sederhana ini dilakukan dengan bantuan program SPSS versi 21.

\section{HASIL DAN PEMBAHASAN}

Dari data yang didapat lalu dianalisis menggunakan uji-t sehingga mendapatkan hasil sebagai berikut.

Tabel 2. Hasil Analisis Regresi Linear Sederhana

\begin{tabular}{|c|c|c|c|c|c|c|}
\hline & \multirow{2}{*}{ Model } & \multicolumn{2}{|c|}{$\begin{array}{c}\text { Unstandardized } \\
\text { Coefficients }\end{array}$} & $\begin{array}{r}\text { Standardized } \\
\text { Coefficients }\end{array}$ & \multirow{2}{*}{$\mathrm{t}$} & \multirow{2}{*}{ Sig. } \\
\hline & & B & $\begin{array}{l}\text { Std. } \\
\text { Error }\end{array}$ & Beta & & \\
\hline \multirow[t]{2}{*}{1} & (Constant) & 3.080 & 1.229 & & 2.507 & .018 \\
\hline & Motivasi & .909 & .035 & .980 & 25.679 & .000 \\
\hline
\end{tabular}

Dari hasil perhitungan tabel 2 maka dapat dibentuk persamaan yaitu : $\mathrm{Y}=3.080$ $+0.909 \mathrm{X}$. Angka koefisien regresi sebesar 3.080. Jika terjadi penambahan motivasi sebesar $1 \%$ maka kinerja pegawai akan meningkat sebesar $.909 \%$. Diketahui pula nilai Sig. dibawah 5\% atau Alpha $<0,00$ maka dapat disimpulkan bahwa ada pengaruh positif dan signifikan Motivasi (X) terhadap Kinerja Pegawai (Y). hal ini selaras dengan hasil penelitian oleh (Pratiwi \& Bagia, 2021; Tangkeallo, 2021) yang menyatakan adanya pengaruh positif dan signifikan antara motivasi terhadap kinerja 
pegawai. Oleh karena itu Dinas Pengelolaan Sumber Daya Air Provinsi Lampung harus selalu memperhatikan halhal yang bisa meningkatkan motivasi pegawainya, agar kinerja bisa meningkat.
Selanjutnya dilakukan uji determinasi $\left(\mathrm{R}^{2}\right)$ untuk untuk mengetahui besarnya pengaruh Motivasi (X) terhadap Kinerja Pegawai (Y) dalam analisis regresi sederhana. Berikut hasilnya:

Tabel 3. Hasil Uji Koefisien Determinasi

\begin{tabular}{|c|c|c|c|c|}
\hline Model & $\mathrm{R}$ & R Square & $\begin{array}{c}\text { Adjusted R } \\
\text { Square }\end{array}$ & $\begin{array}{c}\text { Std. Error of the } \\
\text { Estimate }\end{array}$ \\
\hline 1 &, $980^{\mathrm{a}}$ & .961 & .959 & .76817 \\
\hline
\end{tabular}

Berdasarkan table 3 didapat, Nilai $r$ Square sebesar 0,961 dengan demikian mampu menjelaskan bahwa promosi berkontribusi terhadap keputusan pembelian yaitu sebesar 96,1\% sedangkan 3,9\% dipengaruhi oleh faktor-faktor lain yang tidak diteliti dalam penelitian ini. Std. Error of the Estimate adalah sebesar 0.76817 hal ini menunjukan bahwa semakin kecil Std. Error of the Estimate maka model semakin baik. Atas hal tersebut maka dapat ditarik sebuah kesimpulan bahwa semakin tinggi motivasi Pegawai maka akan meningkatkan kinerja yang baik (Kusumayanti et al., 2020).

\section{KESIMPULAN}

Dari hasil penelitian di atas, didapat hasil bahwa Terdapat pengaruh Motivasi Kerja (X) terhadap Kinerja (Y) pada Pegawai Dinas Pengelolaan Sumber Daya Air Provinsi Lampung. Variabel Motivasi Kerja menjelaskan variasi perubahan terhadap variabel Kinerja pada Pegawai Dinas Pengelolaan Sumber Daya Air Provinsi Lampung sebesar $96.1 \%$, sedangkan sisanya sebesar 3.9\% dijelaskan oleh faktor lain yang tidak dikaji dalam penelitian ini, dalam hal ini variabel Motivasi Kerja, efektifitas, kepemimpinan dan lainnya adalah variabel lain yang sebenarnya mempengaruhi pada saat penelitian ini berlangsung.

\section{DAFTAR PUSTAKA}

Alhusaini, A., Kristiawan, M., \& Eddy, S. (2020). Pengaruh Motivasi Kerja Dan Disiplin Kerja Terhadap Kinerja Guru.
Jurnal Pendidikan Tambusai, 4(3), 2166-2172.

https://doi.org/10.2139/ssrn.3864629

Amirullah, M. (2019). Pengaruh Kompetensi dan Lingkungan kerja Terhadap Kinerja Pegawai BKD Kota Makassar. Jurnal BISNIS \& KEWIRAUSAHAAN, 8(2), 149-158.

Arifuddin, A., \& Napirah, M. R. (2015). HUBUNGAN DISIPLIN DAN BEBAN KERJA DENGAN KINERJA PERAWAT DI RUANG RAWAT INAP RUMAH SAKIT UMUM DAERAH (RSUD) UNDATA PALU. Healthy Tadulako Journal, 1(1), 1-10.

Astawa, I. G. P. B., Julianto, I. P., \& Dewi, L. G. K. (2020). Penilaian Kinerja Koperasi Unit Desa (Kud) Penebel Tabanan Dengan Pendekatan Balanced Scorecard. Monex: Journal Research Accounting Politeknik Tegal, 9(1), 18-29.

Astuti, H. W., \& Tantowi, R. (2017). Pengaruh Iklim Organisasi Terhadap Kinerja Karyawan Pada PT. Bank Danamon Simpan Pinjam Unit Metro. Jurnal Bisnis Darmajaya, 3(2), 163172.

https://doi.org/10.35697/jrbi.v2i1.67

Buulolo, M., Zagoto, R., \& Buulolo, P. (2021). Pengaruh Kompetensi Terhadap Prestasi Kerja Pegawai Pada Kantor Camat Lolowau Kabupaten Nias Selatan. Pareto: Jurnal Riset Bisnis Dan Manajemen, 6(1), 39-44. Dapahari, B. V. (2019). Kualitas Pelayanan Badan Pertahanan Nasional Kota 
Bitung Dalam Pembuatan Sertifikat Tanah. Jurnal Politico, 8(3).

Fathurrochman, I. (2017). Pengembangan Kompetensi Pegawai Aparatur Sipil Negara (ASN) Sekolah Tinggi Agama Islam Negeri (STAIN) Curup Melalui Metode Pendidikan dan Pelatihan. Manajer Pendidikan, 11(2), 120-129.

Hakim, L. (2020). Pengaruh Jaminan Kesehatan Kerja Dan Kompensasi Finansial Terhadap Motivasi Kerja Pegawai (Studi Pada Dinas Pemadam Kebakaran Dan Penanggulangan Bencana Kota Bandung). Ekonam: Jurnal Ekonomi, Akuntansi \& Manajemen, 2(1), 41-47.

https://doi.org/10.37577/ekonam.v2i1.23 0

Herawati, N. R., Isnandi, A. V., \& Sari, Y. E. (2018). Pengukuran Kinerja Koperasi Berbasis Balanced Scorecard. Ekonika: Jurnal Ekonomi Universitas Kadiri, 3(1), 63.

https://doi.org/10.30737/ekonika.v3i1.97

Heryani, A., Iskandar, A., \& Destian, R. (2021). PENGARUH DISIPLIN DAN KEMAMPUAN KERJA TERHADAP KINERJA PEGAWAI PADA BAGIAN PROTOKOL DAN KOMUNIKASI PIMPINAN KOTA BANDAR LAMPUNG Ani Heryani, Ade Iskandar, Rizky Destian. E-JKPP, 7(2).

Jufrizen, J. (2017). Efek Mediasi Kepuasan Kerja Pada Pengaruh Kompensasi Terhadap Kinerja Karyawan. Jurnal IImiah Manajemen Dan Bisnis, 17(01), 34-53.

Kristianti, L. S., Affandi, A., Nurjaya, N., Sunarsi, D., \& Rozi, A. (2021). Pengaruh Motivasi Dan Disiplin Kerja Terhadap Kinerja Pegawai Pada Dinas Pariwisata Purwakarta. Jurnal Ilmiah PERKUSI, 1(1), 101-109. https://doi.org/10.32493/j.perkusi.v1i1.99 87

Kurniaty, H. (2021). Pengaruh Lingkungan Kerja Terhadap Kinerja Pegawai Pada Dinas Kependudukan Dan Pencatatan Sipil Kabupaten Barito Selatan Tahun 2021. Pencerah Publik, 8(1), 1-17. http://journal.umpalangkaraya.ac.id/in dex.php/pencerah\%0A

Kusumayanti, K., Ratnasari, S. L., \& Hakim, L. (2020). Pengaruh Motivasi Kerja, Disiplin Kerja, Lingkungan Kerja, Dan Gaya Kepemimpinan Terhadap Kinerja Pegawai Negeri Sipil Dinas Perindustrian Dan Perdagangan Daerah Pemerintah Kota Batam. Jurnal Bening, 7(2), 178-192. https://www.journal.unrika.ac.id/index .php/beningjournal/article/view/2445

MS, S., Saleh, D., \& Tahir, N. (2018). Kinerja Pegawai Di Terminal Kayu Mangiwang Kabupaten Mamuju Tengah. Kolaborasi: Jurnal Administrasi Publik, 4(2), 201-218.

Netha, M. H. S., \& Tunti, M. D. (2021). Penerapan Prinsip-Prinsip Good Governance dalam Pengelolaan Alokasi Dana Desa di Desa Penfui Timur Kecamatan Kupang Tengah Kabupaten Kupang. Jurnal Akuntansi: Transparansi Dan Akuntabilita, 9(2), 165-171.

Nursin, E. (2018). Pengaruh Pengembangan Sumber Daya Manusia Terhadap Kompetensi Pegawai Pada Dinasd Kependudukan Dan Catatan Sipil Kabupaten Banggai.

Orocomna, C., Tumbel, T. M., \& Asaloei, S. I. (2018). Pengaruh Motivasi Kerja Terhadap Kinerja Karyawan Pada PT. TASPEN (Persero) Cabang Manado. Jurnal Administrasi Bisnis (JAB), 7(1), 66-72. https://doi.org/10.35797/jab.7.001.201 8.21145.66-72

Pratiwi, N. M. D. D., \& Bagia, I. W. (2021). Motivasi Kerja Dan Kemampuan Kerja Mempengaruhi Kinerja Pegawai Pada Pdam Tirta Amertha Jati Kabupaten Jembrana. Jurnal Manajemen Dan Bisnis, 3(1), 22-28.

Ramadhan, A. P., \& Astuti, H. W. (2017). Efektivitas Pelatihan Dan Quality Assurance Terhadap Kinerja Sumber Daya Manusia Pada KFC Gelael 
Lampung. EKOMBIS SAINS: Jurnal Ekonomi, Keuangan Dan Bisnis, 2(1), 25-38.

https://doi.org/10.24967/ekombis.v2i1.47

Rozi, A. (2019). Pengaruh Insentif dan Disiplin Kerja terhadap Kinerja Pegawai pada Kecamatan Citangkil Kota Cilegon. Business Innovation and Entrepreneurship Journal, 1(2), 124229. https://doi.org/10.35899/biej.v1i2.56 Srianti, Ansari, I., \& Ma'ruf, A. (2020). Kualitas Pelayanan Kesehatan di Rumah Sakit Umum Daerah (RSUD) Batara Guru Belopa Kabupaten Luwu. Kajian Ilmiah Mahasiswa Administrasi Publik (KIMAP), 1(2), 410-424.

Sulaeman, M. (2019). Pengaruh Kompetensi Terhadap Kinerja Pegawai Negeri Sipil di Kecamatan Pataruman Kota Banjar. $J$ Politri (Jurnal Manajemen, Keuangan Dan Komputer), 3(1), 57-66.

Sutarmiyati, N., \& Astuti, H. W. (2019). Pengaruh Kompensasi Terhadap Kinerja Karyawan PT Tirta Investama Lampung. Ekombis Sains: Jurnal Ekonomi, Keuangan Dan Bisnis, 4(1), 27-33.

Syarif, A., \& Faurin, N. (2020). Evaluasi Kinerja Sumber Daya Manusia Di Bagian Sdm Pada Perum Bulog Divre Sumsel Babel. Prosiding Semhavok, 64-69. http://conference.binadarma.ac.id/index.p $\mathrm{hp} / \mathrm{semhavok} /$ article/view/1796

Tangkeallo, D. I. (2021). Pengaruh Motivasi Terhadap Kinerja Pegawai Pada Koperasi Serba Usaha Bintang Muda 88 Makale, Tana Toraja. YUME: Journal of
Management, 4(2), 155-163. https://doi.org/10.37531/yume.vxix.34 3

Tinompo, D., Lembo, K., \& Morowali, K. (2016). Kinerja Aparat Desa Dalam Penyelenggaraan Pemerintahan Desa Tinompo Kecamatan Lembo Kabupaten Morowali Utara. Jurnal Eksekutif, 1(1), 1-10.

Triyanto, D. (2017). Analisis Kinerja Organisasi dalam Mewujudkan Pelayanan Prima kepada Masyarakat (Studi Pada Kantor Badan Pelayanan Perizinan Terpadu Kota Semarang). Mimbar: Jurnal Penelitian Sosial Dan Politik, 6(4), 6-13.

Ufaira, R. A., \& Hendrian, W. (2019). Motivasi Kerja Pada Guru Honorer di Indonesia: A Literatur Review. Psikoislamedia: Jurnal Psikologi, 4(2), 212-221.

Wahyuningsih, Sukmawati, S., \& Basalamah, J. (2019). Pengaruh Budaya Organisasi , Motivasi Kerja Dan Etos Kerja Islam Terhadap Kinerja Karyawan Bank Syariah Mandiri Cabang Makassar. Center of Economic Student Journal, 2(2), 125132.

Widhiyaningrat, W. A., \& Idayati, F. (2015). Pengukuran Kinerja Organisasi Nirlaba dari Perspektif Balanced Scorecard pada Rumah Sakit Umum Haji Surabaya. Jurnal Ilmu Dan Riset Akuntansi (JIRA), 4(6), 120. 